\title{
Memetakan Lingkup Informasi Penghidupan Orang Miskin Pedesaan
}

\author{
Pawit M. Yusup, Tine Silvana Rachmawati, Priyo Subekti \\ Departemen Ilmu Informasi dan Perpustakaan Fikom Unpad \\ Jl. Raya Bandung-Sumedang Km. 21 Jatinangor 45363 \\ Email: pawitmy@yahoo.com
}

\begin{abstract}
ABSTRAK - Penelitian ini bertujuan untuk memetakan lingkup informasi penghidupan orang miskin pedesaan, yang meliputi: jenis kebutuhan utama, pola pencarian informasi terkait jenis pekerjaan spesifik, ragam informasi penghidupan yang dicari, hubungan antar orang miskin pedesaan, sumber-sumber informasi, saluran informasi, dan sifat dari sumber dan saluran informasi dimaksud. Dengan menggunakan metode kualitatif khususnya tradisi fenomenologi dari Schutz, diperoleh hasil bahwa: (1) jenis kebutuhan utama orang miskin pedesaan terdiri atas kebutuhan pangan, sandang, papan, kesehatan, dan pendidikan yang sangat sederhana; (2) beragam informasi penghidupan yang dicari oleh orang miskin pedesaan yang sifat pekerjaannya serabutan, berasal dari sumber orang secara interpersonal yang bersifat informal, dengan lingkup yang terbatas, yakni tetangga, kerabat, pelanggan, dan sesama pekerja sejenis; (3) sumber dan saluran yang berasal dari media resmi dan yang berbasis teknologi, hampir tidak pernah digunakan; dan (4) unsur-unsur formal yang datangnya dari sisi pemerintah, hampir tidak menyentuh kepentingan orang-orang miskin pedesaan.
\end{abstract}

Kata kunci: Miskin, Kemiskinan, Pedesaan, Kebutuhan Utama, Pencarian Informasi Penghidupan

ABSTRACT - This study aims to map out the scope of the livelihoods of the rural poor information, which includes: the basic need types, pattern -related information seeking specific types of work, types of livelihood information sought, the relationship between the rural poor, sources of information, information channel, and the nature of the sources and channels of information intended. By using qualitative methods in particular phenomenology of Schutz tradition, the result that: (1) the type of the primary needs of the rural poor consisting of food, clothing, shelter, health, and education are very simple, (2) a variety of livelihood information sought by the nature of the rural poor who work odd jobs, coming from people in interpersonal sources that are informal, with a limited scope, ie, neighbors, relatives, customers, and fellow workers similar, (3) the source and channel are derived from official based on media and technology, almost never used, and (4) formal elements that come from the government side, barely touching the interests of the rural poor.

Keywords: Poor, Poverty, Rural Poor, Basic Needs, Livelihoods Information Seeking

\section{PENDAHULUAN}

\section{Latar belakang penelitian}

Data dari Bank Dunia (2011) menjelaskan bahwa sebagian besar penduduk miskin tinggal di pedesaan (69\%), bekerja di sektor pertanian (64\%), sifat pekerjaan adalah informal (75\%), dan sekitar $22 \%$ adalah sebagai pekerja keluarga yang tidak dibayar. Sementara itu, pada dimensi nonekonomi, konsep kemiskinan terkait dengan kapasitas sumberdaya manusia, aksesibilitas terhadap kebutuhan utama, dan keterlibatan pada kesempatan kerja dan berusaha dalam arti luas, termasuk keterbatasan dalam mengakses dan menemukan informasi mengenai apapun yang bisa dijadikan "pintu" menuju kegiatan usaha untuk memberdayakan diri dan keluarga.

Secara spesifik, sedikitnya ada 8 (delapan) dimensi non-ekonomi penduduk miskin, yakni: (1) ketidakmampuan memenuhi kebutuhan dasar seperti sandang, pangan dan perumahan; aksesibilitas ekonomi rendah terhadap pendidikan, kesehatan, sanitasi, dll.; (3) kemampuan akumulasi kapital dan investasi yang rendah; (4) rentan terhadap goncangan faktor eksternal seperti teknis, alam, ekonomi, sosial, politik); (5) kualitas sumberdaya manusia dan penguasaan sumberdaya alam rendah; (6) terbatasnya keterlibatan dalam kegiatan sosial kemasyarakatan; (7) terbatasnya akses terhadap kesempatan kerja secara berkelanjutan; dan (8) ketidakmampuan berusaha karena cacat fisik dan atau mental (Rusastra dan Napitupulu, 2011).

Penelitian ini tidak bermaksud mengkaji masalah sosioekonomi seperti digambarkan dalam paragraf di atas, namun lebih mengarah dan terbatas pada kajian mengenai pemetaan terhadap 
makna miskin dan kemiskinan pedesaan di pedesaan, terutama dilihat dari aspek variasi jenis kebutuhan utama orang miskin pedesaan seperti kebutuhan akan pangan, sandang, papan, pendidikan, dan kesehatan, yang dikaitkan dengan aspek variasi jenis informasi penghidupan yang dicari dan digunakan mereka sebagai basis survivabilitas kehidupannya. Intinya, bagaimana orang-orang miskin (penduduk miskin) memandang masalah miskin dan kemiskinan; bagaimana mereka mengalami kemiskinannya selama ini; bagaimana mereka menginterpretasikan harapan-harapan akan pengalaman berpenghidupan (livelihood) ${ }^{1}$ sebagai orang miskin yang mendasari survivabilitasnya selama ini; jenis penghidupan seperti apa yang mereka jalani selama ini; dan apa saja jenis kebutuhan utama yang mendasari mereka mencari informasi penghidupan bagi penopang kehidupan keluarganya; adalah rumusan-rumusan kajian pokok yang dikaji secara komprehensif dan mendalam pada penelitian ini.

Penelitian ini lebih difokuskan pada upaya memetakan lingkup informasi penghidupan yang dicari dan dijalani orang miskin pedesaan; yang dalam praktiknya melekat dengan makna pencarian atas beragam jenis pekerjaan yang dijalaninya selama ini, yang merupakan basis survivabilitas kehidupan mereka. Adapun lokasi penelitian difokuskan di sejumlah desa di Kecamatan Banjarsari, Kecamatan Pamarican, Kecamatan Padaherang, dan sejumlah kecamatan lain di bagian Selatan Kabupaten Ciamis, Jawa Barat.

Masalah utama dari penelitian ini adalah bagaimana memetakan lingkup informasi penghidupan orang miskin pedesaan, yang meliputi aspek kebutuhan utama, variasi jenis informasi penghidupan yang dicari, dan pola pencarian informasi yang dilakukannya. Adapun tujuannya adalah untuk memetakan lingkup

\footnotetext{
Livelihood: Sesuatu yang bisa memberikan penghasilan untuk menopang kehidupan seseorang; bisa juga diartikan sebagai pekerjan yang berfungsi sebagai sumber penghasilan suatu penduduk (Kamus Encarta, 2009).
}

informasi penghidupan orang miskin pedesaan sebagaimana tersebut di atas.

\section{KONTRIBUSI PENELITIAN}

Secara teoretis, hasil penelitian ini diharapkan bisa memberikan sumbangan bagi pengayaan dan pengembangan ilmu informasi dan perpustakaan, terutama dalam konteks pencarian informasi penghidupan di kalangan orang-orang miskin pedesaan dengan cara memahami secara lebih komprehensif peta kebutuhan utama yang dirasakan oleh orang-orang miskin pedesaan terkait dengan jenis penghidupan yang mereka cari dan jalani selama ini yang menjadi tumpuan kehidupan diri dan keluarganya. Konteks-konteks perilaku pencarian atau penemuan informasi sebagai bagian dari bidang ilmu informasi dan kepustakaan pun bisa berguna untuk menambah perbendaharaan bidang ilmu sosial lainnya yang bersifat multidisipliner. Selain itu, bisa dijadikan salah satu model dalam "intervensi" pembangunan dari pemerintah dalam upaya mengentaskan kemiskinan di pedesaan, dengan cara melibatkan aspek-aspek keinginan dan pengalaman orangorang miskin dimaksud. Dan, sebagai tambahan sumber informasi yang khas bagi ilmuwan dan peneliti yang berorientasi pedesaan, terutama yang subjek penelitiannya orang-orang miskin pedesaan.

Dalam tataran praktik di lapangan, hasil penelitian ini bisa digunakan sebagai tambahan sumber informasi bagi pemerintah, terutama pemerintah setempat terkait dengan kebijakan-kebijakannya dalam program pemberdayaan penduduk miskin pedesaan yang melibatkan mereka secara fungsional.

\section{TINJAUAN PUSTAKA}

Berikut dikemukakan beberapa kepustakaan terdahulu yang relevan dengan tema penelitian ini: 1. Penelitian Pawit M. Yusup (2012) dengan tema Perilaku pencarian informasi penghidupan pada penduduk miskin pedesaan: Studi fenomenologi mengenai makna miskin bagi penduduk miskin dan perilakunya dalam 
mencari informasi penghidupan di pedesaan kabupaten Ciamis Jawa Barat, menghasilkan informasi bahwa: 1) makna miskin menurut penduduk miskin bersifat kontekstual; 2) makna identitas diri penduduk miskin memiliki konteksnya sendiri yang bersifat subjektif aspektual; 3) pola pencarian informasi penghidupan dilakukan secara akif dan pasif, dengan sumber dan saluran informasi interpersonal yang bersifat informal; dan 4) setiap tindakan yang dilakukan oleh penduduk miskin pedesaan dalam mencari informasi penghidupannya, didasarkan atas motif alasan, motif tujuan, dan motif harapan yang jelas.

2. Pada penelitian selanjutnya, untuk mengkaji lebih dalam mengenai salah satu aspek atau dimensi dari hasil penelitian di atas, penelitian dilanjutkan dengan mengembangkan kajian yang berfokus pada salah satu aspek dominannya, yakni dengan tema atau judul sebagai berikut: Makna Miskin Bagi Penduduk Miskin dan Perilakunya dalam Menemukan Informasi Penghidupan: Studi Fenomenologi di Pedesaan Kabupaten Ciamis Jawa Barat. Adapun fokus kajian penelitian ini adalah pada (1) makna miskin menurut penduduk miskin pedesaan; dan (2) cara pencarian informasi penghidupan pada penduduk miskin pedesaan. Hasil penelitian ini menggambarkan bahwa: 1) Makna miskin menurut pandangan penduduk miskin ternyata mengandung konteks; artinya tidak ada interpretasi tunggal tentang makna miskin dan kemiskinan. Makna miskin bisa dilihat dari konteks: kepemilikan harta benda; konteks upaya dan coba-coba; ketidakberdayaan; konteks bantuan; konteks kemandirian dalam keterpaksaan; konteks harapan; konteks perjuangan; konteks keterbatasan akses informasi; konteks keingintahuan yang rendah; konteks kesederhanaan kebutuhan; konteks keterhinaan; dan konteks kepekaan dalam komunikasi sosial. (2) Cara pencarian informasi yang mereka lakukan berpola aktif dan pasif, dengan sumber informasi yang dicari dan saluran informasi yang digunakannya hampir seluruhnya berupa sumber orang dengan saluran interpersonal yang bersifat informal. Kegiatan penelitian yang kedua ini dibiayai oleh dana BOPTN Unpad 2012 yang termasuk ke dalam Skim PPM Produktif Unpad 2012.

3. Selanjutnya pada akhir tahun 2012 sampai Januari 2013, Pawit M. Yusup dan Neneng Komariah (2013) mendalami satu aspek kunci dari tema penelitian ini yang berfokus pada tema pencarian dan penggunaan informasi kesehatan, dengan judul penelitian: Dimensi Pencarian Dan Penggunaan Informasi Kesehatan Pada Keluarga Prasejahtera di Kabupaten Bandung: Studi Tentang Pemetaan Terhadap Kebutuhan, Pencarian, dan Penggunaan Informasi Kesehatan pada Keluarga Prasejahtera di Kecamatan Rancaekek Kabupaten Bandung. Hasil penelitian menggambarkan bahwa: (1) dilihat dari dimensi kebutuhan, maka yang paling menonjol adalah jenis informasi terkait kebutuhan dasar yang meliputi pangan, sandang, papan, kesehatan, dan pendidikan, (2) dilihat dari dimensi pencarian informasi, yang paling menonjol adalah mengenai cara pencariannya yang dilakukan secara aktif dan pasif dengan sumber dan saluran informasi interpersonal yang bersifat informal, dan (3) dilihat dari dimensi penggunaan informasi, maka yang paling menonjol adalah pada jenis informasi kesehatan yang bersumber pada ahli kesehatan terpilih, dan juga dari tetangga dan keluarga. Mereka tidak ada yang menggunakan informasi yang bersumber dari media, baik cetak maupun elektronik.

4. Philips dan Legates (1981), dalam Badruddin Syamsiah (2009), mengemukakan empat pandangan tentang kemiskinan, yakni: (1) kemiskinan dilihat sebagai akibat dari kegagalan personal dan sikap tertentu khususnya ciri-ciri sosial psikologis individu dari si miskin yang cenderung menghambat 
untuk melakukan perbaikan nasibnya. Akibatnya, si miskin tidak melakukan rencana ke depan, menabung dan mengejar tingkat pendidikan yang lebih tinggi; (2) kemiskinan dipandang sebagai akibat dari subkultur tertentu yang diturunkan dari generasi ke generasi. Kaum miskin adalah kelompok masyarakat yang memiliki subkultur tertentu yang berbeda dari golongan yang tidak miskin, seperti memiliki sikap fatalis, tidak mampu melakukan pengendalian diri, berorientasi pada masa sekarang, tidak mampu menunda kenikmatan atau melakukan rencana bagi masa mendatang, kurang memiliki kesadaran kelas, atau gagal dalam melihat faktor-faktor ekonomi seperti kesempatan yang dapat mengubah nasibnya; (3) kemiskinan dipandang sebagai akibat kurangnya kesempatan, kaum miskin selalu kekurangan dalam bidang keterampilan dan pendidikan untuk memperoleh pekerjaan dalam masyarakat; dan (4) kemiskinan merupakan suatu ciri struktural dari kapitalisme, bahwa dalam masyarakat kapitalis segelintir orang menjadi miskin karena yang lain menjadi kaya. (Syamsiah, 2009).

5. Kepustakaan lain menjelaskan bahwa kriteria penduduk miskin memang berbeda-beda, bergantung kepada pendekatan yang digunakan. Ada dua pendekatan utama untuk menjelaskan penduduk miskin, yakni pendekatan ekonomi dan pendekatan non ekonomi. BPS (Badan Pusat Statistik) melalui pendataan sosial ekonomi tahun 2005 (PSE05) (Sumber: BPS 2008), menggunakan 14 indikator mengenai penduduk miskin, yakni sebagai berikut: (1) Luas lantai rumah; (2) Jenis lantai rumah; (3) Jenis dinding rumah; (4) Fasilitas tempat buang air besar; (5) Sumber air minum; (6) Penerangan yang digunakan; (7) Bahan bakar yang digunakan; (8) Frekuensi makan dalam sehari; (9) Kebiasaan membeli daging/ayam/susu; (10) Kemampuan membeli pakaian; Kemampuan berobat ke puskesmas/ poliklinik; (12) Lapangan pekerjaan kepala rumah tangga; (13) Pendidikan kepala rumah tangga; dan (14) Kepemilikan aset. ${ }^{2}$ Ke-14 indikator tersebut digunakan untuk menjelaskan tingkat kemiskinan penduduk di tingkat mikro atau rumah tangga. Artinya, semakin kecil, semakin rendah, atau semakin menunjukkan ketidakmampuan penduduk untuk memenuhi batas standar minimum dari indikator dimaksud, menunjukkan bahwa penduduk yang bersangkutan termasuk kategori miskin. Namun secara umum dan mudah untuk dipahami adalah bahwa yang termasuk ke dalam penduduk miskin adalah penduduk yang belum dapat memenuhi kebutuhan dasar minimum seperti pangan, sandang, papan, kesehatan, dan pendidikan dasar. Mereka pada umumnya memiliki usaha di sektor informal, yang termasuk ke dalam jenis usaha kecil, bahkan sangat kecil. Kegiatan ekonomi yang dimilikinya belum atau tidak sanggup untuk menutupi atau menghidupi kebutuhan hidup minimum anggota keluarganya. Pengertian usaha (sangat) kecil di sini mencakup usaha kecil informal dan usaha kecil tradisional. ${ }^{3}$ Mereka adalah "pengusaha" kecil yang kurang beruntung (tidak berkembang) namun tetap berperilaku berjuang untuk menghidupi anggota keluarganya.

6. Penelitian Amirudin, (2010) dengan tema Makna Miskin Bagi Penduduk Miskin Di Jawa Tengah (Analisis Mitos Kemiskinan Di Kotamadya Dati II Semarang). Available at link: http://eprints.undip.ac.id/21985/: bahwa hakekat makna miskin bagi si miskin pada intinya merupakan sebuah proses transisi. Sebuah proses yang dibangun minimal oleh dua pasang dimensi oposisi, yakni dimensi penolakan (penolakan terhadap kondisi kemiskinan) dan dimensi penerimaan (penerimaan terhadap cultural realm yang

\footnotetext{
(PSE05) (Sumber: Badan Pusat Statistik 2008).

Sumber: FX Rizal Hartanto, 16 Agustus 2010 pada http://ksupointer.com; diakses tanggal 4 Maret 2011.
} 
dialami). Orang-orang miskin sering mengungkapkan kata-kata "menerima" keadaan, namun pada hakekatnya mereka merasa tidak ingin menjadi miskin. Mereka sebenarnya menerima namun sekaligus menolak keadaan yang sedang dialaminya.

7. Zhao, Y., Zhang, R. \& Klein, K.K. (2009, 411). "Perceived Information Needs And Availability: Results of A Survey Of Small Dairy Farmers In Inner Mongolia". Information Research.. Penelitian ini mengkaji berbagai bentuk penerimaan informasi atas dasar kebutuhan yang berbeda-beda dari para petani susu (pemerah susu) di Mongolia.

8. Dalam serta keefektifannya terkait dengan penggunaan dan penyediaan informasi dimaksud, bisa digunakan sebagai tambahan informasi untuk memperkaya wawasan tulisan ini. Dengan menggunakan teori perilaku informasi (information behavior theory), diperoleh hasil bahwa informasi dari para petani dan sumber informasi dari pasar lebih banyak digunakan dibandingkan dengan informasi dari sumber-sumber teknologi. Sementara itu para petani susu dimaksud yang tingkat pendidikannya relatif lebih tinggi, lebih banyak menggunakan informasi dan sumber-sumber informasi dari sumber-sumber teknologis.

\section{METODE DAN HASIL PENELITIAN}

Metode penelitian kualitatif tradisi fenomenologi dari Schutz (1967) digunakan untuk untuk menjelaskan konsep miskin menurut sudut pandang orang miskin serta pengalamanpengalaman sadar mereka dalam mencari informasi penghidupan selama ini yang dikaitkan dengan pengungkapan variasi jenis kebutuhan utama yang mendasari perilaku pencarian dimaksud. Banyaknya informan yang diteliti adalah 22 orang dengan masing-masing bekerja secara serabutan di sektor pertanian pedesaan. Selain itu, observasi lapangan dan wawancara mendalam juga dilakukan terutama untuk mengeksplor jenis-jenis penghidupan yang dilakukan oleh orang-orang miskin pedesaan. Bagaimana mereka menjalani proses kehidupan dengan beragam jenis penghidupan yang dicari dan dijalankannya selama ini, yang pada tahap prasurvei dan pada hasil penelitian sebelumnya sudah ditemukan tidak kurang dari 55 jenis pekerjaan yang dijalani oleh orang-orang miskin pedesaan. Mereka hidup dengan jenis pekerjaan yang pada umumnya bersifat serabutan, namun mereka bisa bertahan hidup, meskipun penghasilannya tidak mencukupi untuk memenuhi kebutuhan pokok sekalipun (Yusup, 2012).

Jenis-jenis penghidupan seperti dimaksudkan dalam paragraf di atas, masing-masing berbeda satu sama lain. Artinya, masing-masing dari pekerjaan atau bentuk penghidupan dimaksud bersifat unik. Meskipun secara "ekonomi" hampir seluruh jenis penghidupan yang dijalani oleh orang-orang miskin pedesaan tidak pernah mencukupi untuk membiayai kebutuhankebutuhan dasar keluarga mereka, namun pekerjaan tersebut tetap menjadi tumpuan kehidupannya. Beberapa contoh jenis penghidupan dimaksud antara lain adalah: pencari kayu bakar di hutan terdekat, pencari daun pisang untuk dijual di pasar-pasar tradisional, pencari dan penggali bonggol-bonggol kayu untuk dijadikan kayu bakar dan dijual ke tetangga, pencari ikan di kali dan ri rawa-rawa terdekat, pedagang jajanan anak yang dijajakan secara keliling dengan digendong, pencari sayuran yang tumbuh liar di sawah, pencari keroto untuk pakan burung, dan jenis pekerjaan lain yang bersifat khas.

Jenis-jenis penghidupan ini nantinya dijelaskan dan dikaji satu per satu untuk kemudian dikategorisasikan dan dicari kesamaan atau perbedaan khasnya sehingga bisa dipetakan secara jelas. Hasil pemetaan ini kemudian dikaitkan dengan variasi jenis kebutuhan utama dari pelaku pekerjaan (usaha) dimaksud. Model pemetaan dari kedua dimensi tersebut, yakni variasi jenis kebutuhan dan dimensi jenis pekerjaan ini, diharapkan bisa menggambarkan pola hubungan yang jelas antara keduanya. 
Gambar berikut disusun guna memetakan lingkup informasi penghidupan orang miskin pedesaan, mulai dari dimensi kebutuhan utama, pola mencari informasi penghidupan yang dilakukan secara pasif dan aktif, ragam informasi penghidupan serabutan, sumber dan saluran informasi, media yang digunakan, lingkup garis putus-putus). Lihat gambar berikut: komunikasi yang terbatas, dan sumber-sumber resmi yang hampir tidak pernah digunakan. Hubungan antar aspek dalam peta gambar dimaksud disifati oleh pola hubungan langsung (dilambangkan dengan garis tidak putus) dan hubungan tidak langsung (dilambangkan dengan

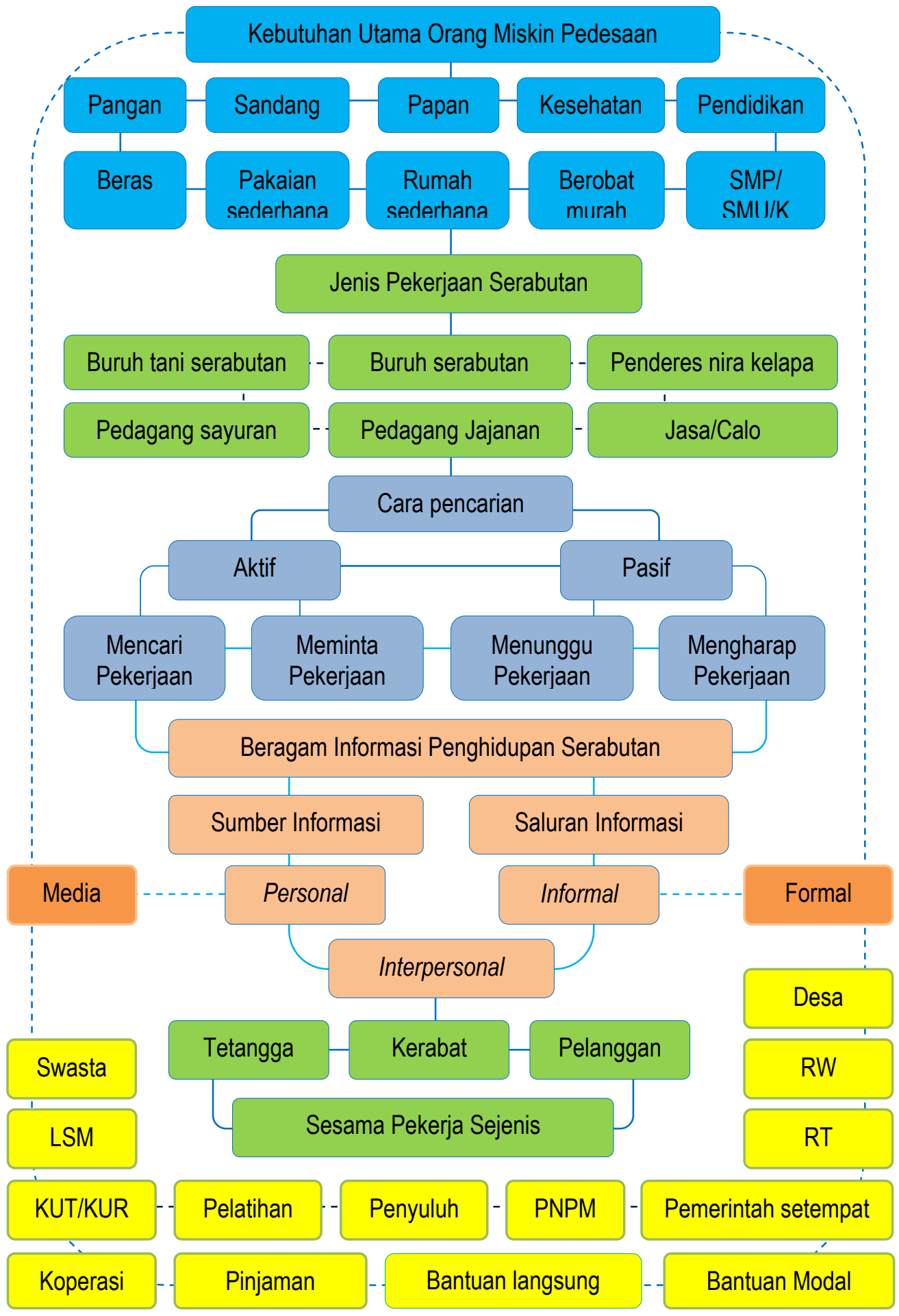

Peta Lingkup Pencarian Informasi Penghidupan terkait Kebutuhan Dasar

Keterangan Gambar:

- Garis lurus melambangkan pola hubungan langsung

- Garis lurus putus-putus melambangkan pola hubungan tidak langsung 


\section{PENUTUP}

Dari peta gambar di atas, bisa disusun suatu hasil konstruksi realitas yang menggambarkan pola hubungan dan lingkup informasi penghidupan dari orang-orang miskin pedesaan, sebagai berikut:

1) Jenis kebutuhan utama orang-orang miskin pedesaan terdiri atas kebutuhan pangan, sandang, papan, kesehatan, dan pendidikan.

2) Jenis kebutuhan utama pada tataran praktik adalah beras, pakaian sederhana, rumah sederhana, asal tidak sakit dan kalaupun sakit bisa berobat murah bahkan gratis, dan anak-anak bisa sekolah sampai tingkat lanjutan.

3) Pencarian informasi penghidupan yang dilakukan oleh orang-orang miskin pedesaan terkait dengan jenis pekerjaan spesifiknya, yang dilakukan dengan cara aktif dan pasif, yakni mencari dan menunggu pekerjaan.

4) Beragam informasi penghidupan yang dicari oleh orang-orang miskin pedesaan yang sifat pekerjaannya serabutan, berasal dari sumber dan saluran interpersonal yang bersifat informal, dengan lingkup yang terbatas, yakni tetangga, kerabat, pelanggan, dan sesama pekerja sejenis.

5) Hubungan antar orang miskin pedesaan yang berbeda pekerjaan, bersifat tidak langsung. Hampir tidak terjadi komunikasi di antara mereka, terutama yang berkaitan dengan proses pencarian informasi penghidupannya.

6) Sumber dan saluran yang berasal dari media dan yang berbasis teknologis, hampir tidak pernah digunakan oleh orang-orang miskin pedesaan dalam proses pencarian informasi penghidupannya

7) Sumber informasi penghidupan yang berasal dari unsur-unsur formal atau resmi, hampir tidak pernah digunakan oleh orangorang miskin pedesaan dalam proses pencarian informasi penghidupannya.
8) Unsur-unsur formal yang datangnya dari sisi pemerintah yang terkait dengan fungsi pengentasan kemiskinan pedesaan, hampir tidak "menyentuh" kepentingan orangorang miskin pedesaan.

\section{DAFTAR PUSTAKA}

Amirudin. 2010. Makna Miskin Bagi Penduduk Miskin Di Jawa Tengah (Analisis Mitos Kemiskinan Di Kotamadya Dati II Semarang). Diakses dari http://eprints.undip. ac.id /21985/

Bank Dunia. Diakses tanggal 1 Agustus 2011 pada: http://go.worldbank.org,

Hartanto, FX Rizal. Diakses tanggal 4 Maret 2011 pada http://ksupointer.com.

Rusastra, I. Wayan dan Napitupulu, Togar A., 2011. Karakteristik Wilayah Dan Keluarga Miskin Di Pedesaan: Basis Perumusan Intervensi Kebijakan. Pusat Analisis Sosial Ekonomi dan Kebijakan Pertanian dan UNESCAP-CAPSA: Bogor.

Schutz, Alfred. 1967. Editor George Walsh dan Frederick Lehnert. "The Phenomenology of te Social World". Northwestern University Studies in Phenomenology \& Existential Philosophy. Illinois: Northwestern University Press.

Syamsiah, Badruddin. 2009. Kemiskinan dan Kesenjangan Sosial di Indonesia Pra dan Pasca Runtuhnya Orde Baru. Diakses dari http://profsyamsiah.wordpress.com/ 2009/04/23/49/

Yusup, Pawit M. 2012. Makna Miskin Bagi

Penduduk Miskin dan Perilakunya dalam Menemukan Informasi Penghidupan: Studi Fenomenologi di Pedesaan Kabupaten Ciamis Jawa Barat. LPPM Unpad.

Yusup, Pawit M. 2012. Perilaku Pencarian Informasi Penghidupan Pada Penduduk Miskin Pedesaan: Studi Fenomenologi Mengenai Makna Miskin Bagi Penduduk Miskin Dan Perilakunya Dalam Mencari Informasi Penghidupan Di Pedesaan 
Kabupaten Ciamis Jawa Barat. PPs Unpad, Bandung.

Yusup, Pawit M. dan Neneng Komariah. 2013.

Dimensi Pencarian Dan Penggunaan

Informasi Kesehatan Pada Keluarga

Prasejahtera di Kabupaten Bandung: Studi

Tentang Pemetaan Terhadap Kebutuhan,

Pencarian, dan Penggunaan Informasi

Kesehatan pada Keluarga Prasejahtera di

Kecamatan Rancaekek Kabupaten Bandung.

LP3 Fikom Unpad.

Zhao, Y., Zhang, R. \& Klein, K.K. 2009.

"Perceived Information Needs And Availability: Results Of A Survey Of Small Dairy Farmers In Inner Mongolia". Information Research, 14(3) paper 411. Diakses dari http://InformationR.net/ir/143/paper411.html]. 